\title{
Detection of Enterocytozoon hepatopenaei (EHP) DNA in the polychaetes from shrimp ponds suffering white feces syndrome outbreaks
}

\author{
DESRINA", SLAMET B. PRAYITNO, ALFABETIAN HARJUNO CONDRO HADITOMO, \\ RUSTHESA LATRITIANI, SARJITO SARJITO \\ Department of Aquaculture, Faculty of Fisheries and Marine Sciences, Universitas Diponegoro. Jl. Prof. Soedharto, S.H. Tembalang, Semarang 50275. \\ Central Java, Indonesia. Tel.: +62-24-7474698, `email: rinadesrina@ yahoo.com
}

Manuscript received: 13 August 2019. Revision accepted: 30 December 2019.

\begin{abstract}
Desrina, Prayitno S B, Haditomo A H C, Latritiani R, Sarjito S. 2020. Detection of Enterocytozoon hepatopenaei (EHP) DNA in the polychaetes from shrimp ponds suffering white feces syndrome outbreaks. Biodiversitas 21: 369-374. Enterocytozoon hepatopenaei (EHP) is the newly emerging pathogen of farmed shrimp in Asia. EHP was associated with white feces syndrome (WFS) in shrimp because the spores existed in the feces of shrimp with WFS. Polychaetes are benthic invertebrates and potential to contribute to EHP outbreaks in a pond by acquiring the pathogen and transfer it to shrimp upon feeding. The objective of this study was to determine (1) the occurrence of EHP in polychaetes with Giemsa staining of the coelomic fluid, 1-step PCR and histopathology and (2) to determine pathological changes of EHP infected tissues. Polychaetes were obtained from 20 shrimp ponds located in 9 districts along the North Coast of Java Island, Indonesia. There were no EHP spores detected in the stained coelomic fluid. The 1-step PCR analysis was able to detect the EHP DNA (prevalence was 10\%). The Alignment of EHP DNA sequence found in polychaetes showed 100\% identity with a published sequence. Histopathological examination showed hypertrophy cells and nuclei, however, no EHP mature spores were found in the epithelial cells on the mucosal layer of the stomach and intestines. Although methods used did not give the convergence results, however, a result of PCR and sequence analysis showed that EHP occurred in the polychaetes in the WFS infected ponds at low point prevalence.
\end{abstract}

Keywords: Enterocytozoon hepatopenaei, microsporidia, polychaetes, shrimp, white feces syndrome

\section{INTRODUCTION}

Enterocytozoon hepatopenaei (EHP) (fungi: Microsporidia) is the etiological agent of hepatopancreas microsporidiosis (HPM), an emerging disease of farmed shrimp in South East Asia (Thitamadee et al. 2016). The disease does not have specific gross clinical signs, however severe slow growth has been reported (Rajendran et al. 2016). Although no economic loss calculated yet, escalation of production cost due to high feed conversion ratio, lower weight yield and longer production time is unavoidable. The parasite was described for the first time by Tourtip et al. (2009) in the Penaeus monodon in Thailand. Subsequently, E. hepatopenaei outbreaks were reported in Pacific white shrimp Penaeus vannamei in Vietnam (Ha et al. 2010), Thailand (Tangprasittipap et al. 2013), and India (Rajendran et al. 2016). E. hepatopenaei infection in P. vannamei was reported in Indonesia for the first time in Situbondo in 2015 and the parasite can be transmitted horizontally to healthy shrimp through cannibalism and cohabitation (Tang et al. 2016). In India and Indonesia, the EHP infection was associated with the white feces syndrome (WFS) in the cultured penaeid shrimp (Rajendran et al. 2016; Tang et al. 2016).

Microsporidiosis commonly occurs in aquatic invertebrates (Micieli et al. 2000; Solter 2014). Stentiford and Dunn, (2014) listed 50 genera of pathogenic microsporidia of aquatic arthropods living in various niche, indicating the adaptability of Microsporidia to the aquatic environment. Microsporidia undergo vegetative and spore stages in which the spore is the infectious stage and the only stage survives outside the host (Vávra Ronny Larsson 2014). EHP spores were discharged to the environment in the fecal of shrimp suffered the WFS (Rajendran et al. 2016). Furthermore, the pond bottom containing organic matter may be beneficial for the survival of the spores in the pond environment and infect the susceptible benthic invertebrates that naturally abound in shrimp ponds.

Polychaetes are ubiquitous benthic invertebrates that naturally abundance in the shrimp ponds and serves as natural food for shrimp (Varadharajan and Soundarapandian 2013). Polychaetes found in shrimp ponds are filter-feeder and detrital-feeder. We hypothesized that the niche and feeding habit of polychaetes exposes them to many shrimp pathogens sink in the sediment, thus, making them potential vectors. Desrina et al. (2013) and Haryadi et al. (2015) showed that polychaete Dendronereis spp. are host of the white spot syndrome virus (WSSV) in shrimp ponds. The detection of EHP DNA in polychaetes using PCR (Thitamadee et al. 2016), indicating that polychaete can be a host or/and a vector of EHP. Polychaetes may acquire the EHP spores by ingesting spores that settled in the sediment. Identifying the carriers and reservoir hosts that can be the source of infection is 
crucial to design control measures of EHP and related WFS. As the newly described and newly emerging pathogen, no information about the life cycle and host range of EHP available yet. In this study, we intend to detect the occurrence of EHP in polychaetes from the WFS infected pond. EHP was detected with staining of fresh smear, 1-step PCR and histopathology examination. To the best of our knowledge, this is the first in-depth investigation of EHP in benthic invertebrate other than shrimp in shrimp ponds.

\section{MATERIALS AND METHODS}

\section{Preliminary survey}

The purpose was to get an overview of the research location in shrimp producing districts on the North Coast of Java island. Sample ponds were located in the following districts: Kendal, and Demak (Central Java Province), Situbondo, Tuban and Sidoarjo (East Java Province) and Indramayu, Cirebon, and Subang (West Java Province). The main criteria for the sample ponds were: (i) Affected by white feces syndrome within one year of the survey. (ii) The presence of polychaete based on the result of the interview with the owner/operator and (iii) Cooperative owner. We conducted a preliminary survey to obtained disease history by interviewing the extension service officers, visiting the potential pond location and interview the owners or pond managers.

\section{Sample collection}

Polychaetes were collected from 21 shrimp ponds experienced WFS and selected WFS-free ponds located in the shrimp production area mentioned above. Each pond was divided into grids with the distance between grids was $25 \mathrm{~m}$ along the length of the pond. Sediment containing polychaetes was lifted with a bucket (volume $10 \mathrm{~L}$ ), sieved through a series of sieve shaker, counted, washed in the clean brackish water and then in sterile seawater. Worms were brought to the lab alive in a plastic bucket. Polychaetes for EHP detection with histopathology and PCR were processed immediately according to the protocols described below. The rest of polychaetes were stored at $-80{ }^{\circ} \mathrm{C}$ and $-20{ }^{\circ} \mathrm{C}$ for future used. Specimens for PCR were stored in either $96 \%$ ethanol at room temperature or $-20{ }^{\circ} \mathrm{C}$ until used. A total of 142 polychaetes were used for fresh smear examination, PCR, and histopathology. Due to damage from drawing the body fluid, different individual of polychaetes was used for fresh smear examination, PCR, and histopathology.

\section{Detection of EHP in the polychaete coelomic fluid}

Fresh smear was prepared from the coelomic fluid. Polychaete was placed on a sheet of paper towel to blot the liquid and mucus on the body surface and placed in a sterile petridish until they relax. Hemolymph was drawn with the sterile tuberculin syringe by gently put pressure on the front part of the body until it showed gentle raise due to accumulation of the body fluid. Immediately, the needle was inserted to drawn coelomic fluid and placed directly on the object-glass by unscrewed the needle and pushed the plunger. Thin smear was prepared by placing the second object-glass on the liquid at $45^{\circ}$ angels and quickly move the second object-glass toward the end of the first objectglass. Smear was fixed in $70 \%$ methanol for 15 minutes, stained with Giemsa for 5 minutes (Praveena et al. 2018) and examined under the light microscope at $1000 \mathrm{X}$ magnification.

\section{PCR to detect the occurrence of EHP in polychaetes DNA extraction from polychaete}

Two to three polychaetes from each pond were tested for EHP using PCR. Total DNA was extracted from segments 20-30 (front region of polychaete) according to Desrina et al. (2013) using Dneasy Blood and Tissue (Qiagen) following manufacturer instruction. Extracted DNA concentration was determined with spectrophotometer (Nanodrop, Thermofisher) by measuring UV absorption at 260 nmat and stored at- $20{ }^{\circ} \mathrm{C}$ freezer until used.

\section{PCR to detect EHP DNA in polychaete}

PCR to detect EHP DNA was done according to Tang et al. (2015) using primer pairs EHP-510 (Tang, et al. 2015). The Sequence of primers pairs used was EHP510F: 5'GCCTGAGAGATGGCTCCCACGT3' and EHP510R: 5'-GCGTACTATCCCCAGAGCCCGA3'. Positive (DNA obtained from previously confirmed EHP case, kindly provided by Bambang Hanggono, Brackishwater Aquaculture Development Center, Situbondo, Indonesia) and negative controls (nuclease-free water) were run simultaneously with the tested specimens. Each specimen was tested individually and replicated once to ensure the consistency of the result.

The PCR reaction contains $40-50 \mathrm{ng} / \mu \mathrm{L}$ of DNA, ten pmol of each forward and reverse primer, $0.5 \mu \mathrm{L}$ of dNTP $(10 \mathrm{mM}), 5 \mu \mathrm{L}$ of $5 \mathrm{X}$ PCR buffer (Promega), $1.5 \mu \mathrm{L}$ of $\mathrm{MgCl}_{2}(25 \mathrm{mM})$ and $2.5 \mu \mathrm{L}$ of GoTaq Flexy DNA Polymerase (Promega) in a $0.2 \mathrm{~mL}$ PCR tube (final reaction volume $25 \mu \mathrm{L}$ ). PCR process used the Gene Amp PCR System 9600 (Applied Biosystems, Foster City, USA).

The PCR conditions were as follows: initial denaturation $\left(94^{\circ} \mathrm{C}, 3 \mathrm{~min}\right)$, followed by 35 cycles of denaturation $\left(94^{\circ} \mathrm{C}, 30 \mathrm{sec}\right)$, annealing $\left(60^{\circ} \mathrm{C}, 30 \mathrm{sec}\right)$ and elongation $\left(72^{\circ} \mathrm{C}, 30 \mathrm{sec}\right)$ and a final extension at $72^{\circ} \mathrm{C}(5$ $\mathrm{min})$. The result of PCR products was analyzed by electrophoresis in $1 \%$ agarose gels and visualized with an UV illuminator Gel Doc XR System (Biorad). The size of amplicons was estimated with a 100 bp DNA ladder.

\section{Sequencing of EHP 18S rRNA gene}

Selected PCR products of EHP DNA of 18S rRNA gene were sequenced ( $1^{\text {st }}$ Base Laboratory, Selangor, Malaysia). The results were aligned using the BLAST program (www.ncbi.nlm.nih.gov) to determine the homology of the EHP gene obtained in this study with those of known sequences contained in the GenBank. 


\section{Histopathological examination to detect EHP spores and pathological changes}

The specimens for PCR and histopathology were prepared separately (1-2 worm/pond). Collected polychaetes were preserved in Davidson's solution for $48 \mathrm{~h}$ and subsequently were moved to $70 \%$ ethanol. Specimens were processed, mounted in paraffin, sectioned $5 \mu \mathrm{m}$ and stained with hematoxylin and eosin (H\&E) (Desrina et al. 2013). Only live polychaetes were used in histopathology examination. Histopathological changes and occurrence of EHP spores examined with a light microscope.

\section{RESULTS AND DISCUSSION}

\section{Overview of shrimp diseases in the surveyed area}

In the current study, we used the occurrence of WFS in cultured shrimp as an indication of EHP infection in shrimp. The association of EHP with the WFS outbreak in the shrimp ponds was conflicted. Tangprasittipap et al. (2013) reported earlier that there is no association between WFS and EHP and the pathogen was not transmissible horizontally. In contrast, the newly published work by Tang et al. (2016) reported that infection of EHP was associated with the occurrence of WFS and that this disease was transmittable. Thus, it ensured the samples we took for the current study was originated from the EHP infected pond since all of ponds surveyed experienced WFS outbreak.

In addition to WFS, diseases caused by infectious Myonecrosis virus (IMNV), Taura syndrome virus (TSV) and White spot syndrome virus (WSSV) were also the major problem for the shrimp farming in the survey area as shown by gross clinical signs on the shrimp. All ponds had a history of at least two following viral diseases WSSV, IMNV and TSV with WSSV the most prevalent one. It was not clear at this point whether these pathogens linked to the occurrence of WFS or EHP in the ponds we surveyed. However, the interaction among pathogens in the semiopen system such as shrimp ponds could not be dismissed. Aranguren et al. (2017) reported that EHP was a risk factor for two newly emerging diseases of farmed shrimp, acute hepatopancreatic necrosis disease (AHPND) and septic hepatopancreatic necrosis (SHPN). Recently, Han et al. (2019) reported that WSSV is a risk factor for APHND. Thus, the presence of EHP and the fact that WSSV is endemic in Indonesia can be an alarm for the shrimp farming industry in Indonesia to watch out for APHND, which was not reported in Indonesia so far.

\section{Pond sampling, polychaete species found and polychaete density}

All case ponds experienced WFS within 1 month to 6 months of sampling. Getting permission to do sampling is the main obstacle in this research, therefore, all ponds were sampled only once at a post-harvest time. Species of polychaetes found consisted of Dendronereis spp, Marphyssa spp, and Nereis sp. The polychaete density ranged from 12 to $60 \mathrm{ind} / \mathrm{m} 2$ (Table 1) and was highly varied among the ponds, even among the ponds within one location. All of the polychaetes found were a burrower and known as the natural feed of shrimp.
Among the three worm species found in the current study, only 2 species were reported as a vector for shrimp pathogens. WSSVwas reported transmitted by Dendronereis spp. (Desrina et al. 2013, Haryadi et al. 2015) and Marphyssa (Vijayan et al. 2005). The density of polychaetes in shrimp ponds in this study relatively low because of sampling was done after harvest. Predation by shrimp during the production period caused low polychaete density at the end of the production period. Studies in the shrimp ponds showed that the dynamic of macrobenthos was influenced by Penaeus subtilis (Nunes and Parson 2000) and in subtidal sediment by Litopenaeus setiferus (Pollack et al. 2009). Polychaetes are preferred food of shrimp P. monodon event at the post-larval stage (Gatune et al. 2014) that causes the polychaete density decline as the shrimp grows.

\section{Detection of EHP in the polychaete fresh smear}

There were no microsporidia spores and cysts observed in the coelomic fluid smear stained with Giemsa. Likewise, there were no clinical signs seen on gross pathology observation may be caused by the infection in the polychaetes specimen we examined was light or not occurred at the same stages as in shrimp. Kummari et al. (2018) stated that there were 2 EHP diagnosis approach namely (i) DNA Based and (ii) Microscopic based. DNA based consisted of polymerase chain reaction (PCR) and Loop-Mediated Isothermal Amplification (LAMP), while microscopic based consisted of hematoxylin and eosin, in situ hybridization, scanning electron microscopy, and transmission electron microscopy. Giemsa stain is the simplest method and was used to detect microsporidia spores in human, and fish. Proveena et al. (2018) detected EHP spores on the purified specimens, however, suggested that the use of counterstain will improve the result. The occurrence of EHP DNA as shown by PCR result (below), indicating that the EHP spores entered the polychaetes presumably through the oral route. However, further study is needed to determine if polychaetes is part of the EHP outbreaks in the shrimp pond.

\section{PCR to detect the occurrence of EHP in polychaete}

We were able to detect the EHP DNA in 5 out of 50 of polychaetes specimens tested using PCR with EHP 510 primer pairs (Table 1). Examples of electrophoresis visualization from PCR amplification using primers for $18 \mathrm{~S}$ rRNA produced single bands of DNA fragments at a size of about 514 bp amplicons (Figures 1.A and 1.B). The point prevalence of the EHP-PCR positive polychaetes was $10 \%$. Selected PCR results are presented in Figure 1. The intensity of the bands is weak and thin, indicating that the amount of EHP DNA in these polychaetes is low. Rajendran et al. (2016) stated that there was a relation between WFS and EHP infection in shrimp in terms of the prevalence rate. Prevalence rate was $39.7 \%$ without WFS whilst WFS was $96.4 \%$. However, no information available so far about the prevalence of EHP in other benthic invertebrates. Further study is needed to determine the life history of E. hepatopenaei and all susceptible host(s) and vector(s) that may present in the shrimp ponds. This 
information is important for EHP control to prevent shrimp production loss.

\section{Sequencing of EHP 18S rRNA gene}

Alignment of EHP DNA sequences isolated from polychaetes with EHP gene sequences available in the GenBank database (NCBI) indicating EHP tested in this study was $100 \%$ identical with Enterocytozoon hepatopenaei 18S rRNA (Accession Number KX932041) which was successfully isolated from P.vannamei in India.

\section{Histopathological examination}

Polychaetes worms did not show any clinical signs upon gross pathological examination. All worms were active and had normal coloration. There was a different condition of tissues of polychaetes obtained from WFS affected and not affected pond. Gut tissues of polychaete Dendronereis spp. from WFS-free shrimp pond appeared intact without pathological changes (Figure 2.E). Although there were no histopathological changes associated with EHP infection and there were no EHP spores observed in the polychaetes obtained from WFS affected ponds, however, some specimens showed pathological changes such as enlargement of the nucleus of the epithelial cells on the mucosal layer of the intestine, and occasionally have multiple nuclei (Figures 2.A, B, and C). We also observed severe hypertrophy of the epithelial cells that resulted in the epithelial lining separated from the underlying tissues (Figure 2.D). Kummari et al. (2018) stated that histologically, there were severe necrotic changes seen in the shrimp hepatopancreas of EHP infected shrimp.

The histopathological changes we observed in polychaetes in this study could be attributed to (i) infection of other pathogens that may present in the pond such as haplosporidia and WSSV (manuscript in preparation). (ii) We hypothesized that the EHP existed in the polychaetes at an early stage. According to Vavra and Larson (2013) and Stentiford et al. (2014), one common pathological effect on the host during sporogeny was the nuclei of the cells were enlarged, located at the peripheral and contained immature spores. Lack of mature spores in the tissue we examined indicating that EHP may be developed, rather, used polychaetes as the intermediate host.
Thitamadee et al. (2016) reported the presence of EHP DNA in polychaetes however, they did not specify the source of the polychaetes. In this study, we detected the EHP 18S rRNA gene in the polychaetes collected from shrimp ponds at the expected size and confirmed with BLAST analysis. Our finding demonstrated that polychaetes lived in the WFS infected shrimp ponds carry the EHP albeit at low prevalence. The intensity of the bands was weak and thin, indicating that the amount of EHP DNA in these polychaetes was small. This hypothesis might in line with Vávra, and Larsson (2014) that microsporidia have a complex life cycle, started and end with the formation of mature spores that may develop in more than one host.

Table 1. Polychaete density in sampled ponds and results of PCR analysis to detect EHP DNA in polychaetes

\begin{tabular}{|c|c|c|c|c|}
\hline \multirow[b]{2}{*}{$\begin{array}{l}\text { No of } \\
\text { pond }\end{array}$} & \multirow[b]{2}{*}{$\begin{array}{c}\text { Pond } \\
\text { location }\end{array}$} & \multicolumn{2}{|c|}{ Polychaetes } & \multirow[b]{2}{*}{$\begin{array}{l}\text { PCR } \\
\text { results }\end{array}$} \\
\hline & & $\begin{array}{l}\text { Density } \\
\text { (ind// } \mathbf{m}^{2} \text { ) }\end{array}$ & $\begin{array}{l}\text { No of } \\
\text { tested }\end{array}$ & \\
\hline Pond 1 & Demak & 18 & 3 & 0 \\
\hline Pond 2 & Demak & 30 & 2 & 0 \\
\hline Pond 3 & Demak & 26 & 2 & 1 \\
\hline Pond 4 & Demak & 32 & 2 & 0 \\
\hline Pond 5 & Kendal & 12 & 2 & 0 \\
\hline Pond 6 & Kendal & 28 & 2 & 0 \\
\hline Pond 7 & Kendal & 24 & 2 & 0 \\
\hline Pond 8 & Rembang & 24 & 2 & 0 \\
\hline Pond 9 & Rembang & 28 & 2 & 0 \\
\hline Pond 10 & Tuban & 26 & 2 & 0 \\
\hline Pond 11 & Tuban & 60 & 3 & 0 \\
\hline Pond 12 & Tuban & 46 & 3 & 1 \\
\hline Pond 13 & Sidoarjo & 50 & 3 & 1 \\
\hline Pond 14 & Indramayu & 38 & 2 & 0 \\
\hline Pond 15 & Indramayu & 40 & 3 & 0 \\
\hline Pond 16 & Indramayu & 37 & 2 & 0 \\
\hline Pond 17 & Cirebon & 35 & 2 & 0 \\
\hline Pond 18 & Cirebon & 20 & 2 & 0 \\
\hline Pond 19 & Subang & 20 & 2 & 1 \\
\hline Pond 20 & Subang & 40 & 4 & 1 \\
\hline \multirow[t]{2}{*}{ Pond 21} & Subang & 41 & 3 & 0 \\
\hline & Total & & 50 & 5 \\
\hline
\end{tabular}
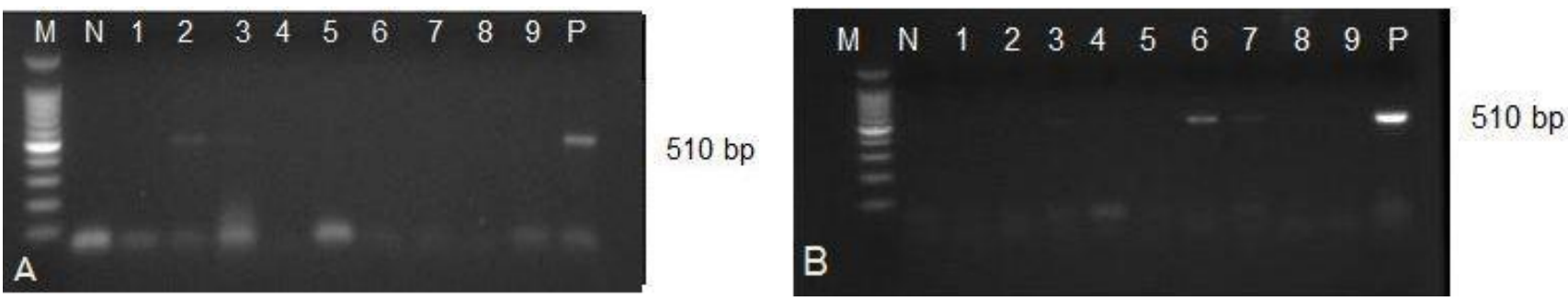

Figure 1. Results of PCR to detect EHP DNA in the polychaetes obtained in this study using primer pairs EHP 510 (Tang et al. 2015). $\mathrm{M}=$ Marker (100 bp DNA ladder), N= Negative control (Nuclease free water), P= Positive control (DNA obtained from EHP infected (Penaeus vannamei) Lane 1-9= DNA of polychaetes specimens tested. The size of the expected amplicon is $510 \mathrm{bp}$ 


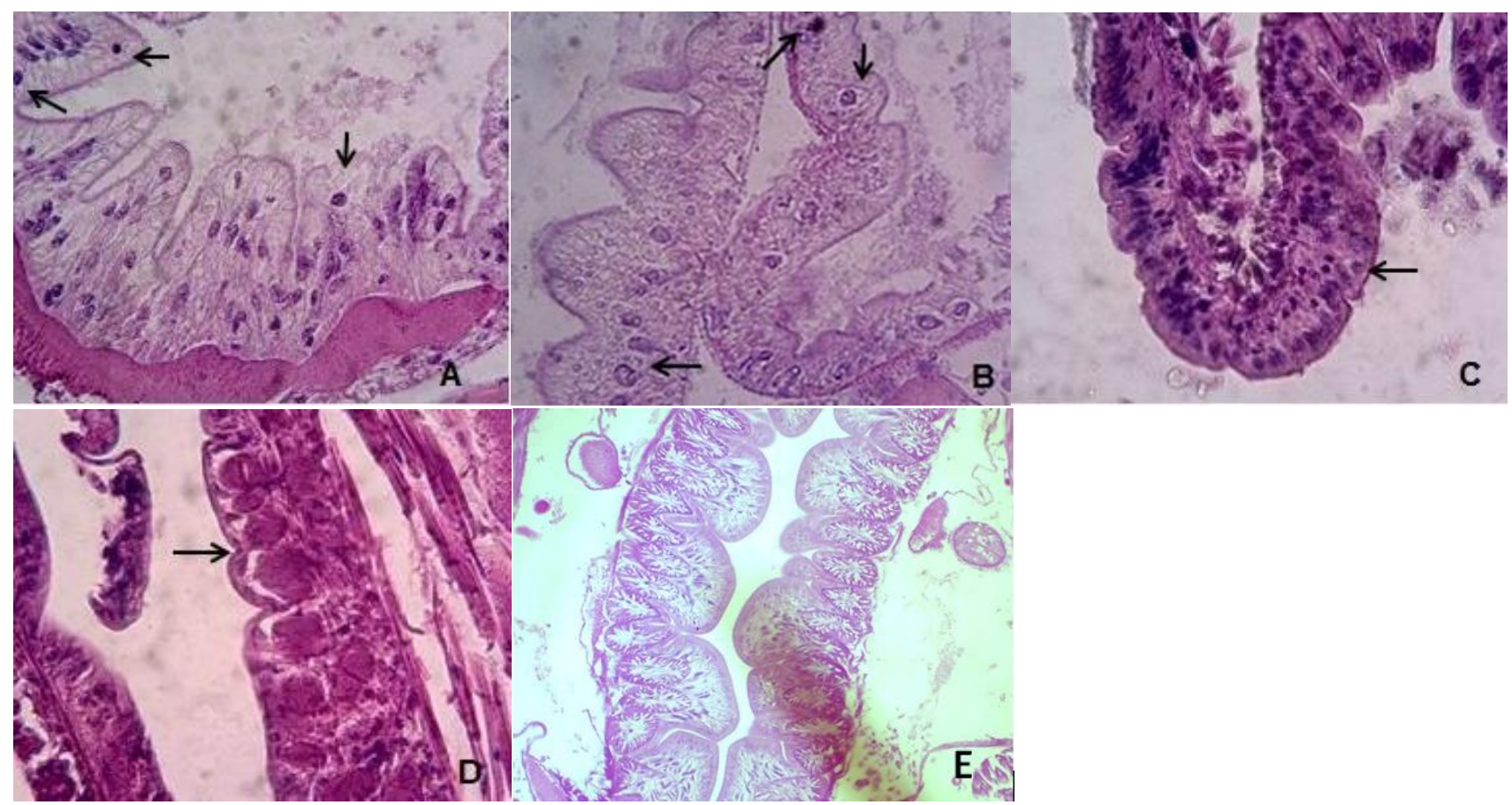

Figure 2. Histopathological changes in the gut of polychaetes observed in this study, however, none of the specimens showed specific changes that indicated EHP infection. A and B. Intestine of Dendronereis spp. from WFS infected ponds in Tuban and Kendal with enlarged and intense basophilic nuclei of epithelial cells of the mucosal layer. C. The intestine of Marphyssa spp from WFS infected pond in Tuban showing many cells with enlarge and intense basophilic nuclei. D. Hypertrophy of epithelial cells that cause epithelial lifting. E. Gut of Dendronereis spp. from WFS-free ponds (H\&E, Magnification 400X)

Developmental stages of EHP in shrimp has been described by Tourtip et al. (2009), however, there is no information about the occurrence of EHP in other animals in shrimp ponds. The mature spores of EHP is acidophilic and oval in shape (Tourtip et al. 2009; Tangprasittipap 2013) that resides in the epithelial cells of the hepatopancreas of the shrimp (Rajendran et al. 2016). As intracellular parasites, EHP depends mainly on the host cells for its development in the nutrient-rich tissue such as hepatopancreas. Therefore, hepatopancreas is very suitable to support the development of EHP. Since polychaetes do not have hepatopancreas, this study used anterior segments of polychaetes that contains gut tissue and remained of coelomic fluid to detect EHP with PCR. Thus, it is possible that presence of EHP DNA in polychaetes may not be limited in the gut organs.

In conclusion, our findings showed that the EHP DNA was occurred in the polychaetes live in the WFS affected shrimp ponds. Although the histological examination did not clearly show the presence of EHP cysts, the histopathological changes suggested that the tissue was infected with intracellular pathogen. It is possible that the EHP presence in the polychaetes at different stages than that find in the cultured shrimp. We incline to conclude that EHP occurs in polychaetes but not at the mature stage.

\section{ACKNOWLEDGEMENTS}

Diponegoro University, Semarang, Indonesia funded this research through Research Grant for International Publication (PNBP DIPA Diponegoro University No. 022/SP2H/LT/DRPM/II/2016). We thank farmers and all students (Tiara Puspa Anjani, Hendra Kusuma Putra, Yosef Toni, M. Falah, Hanifa, M.Shofa and Rizki Fajar) who helped to collect polychaetes from the fields. We also thank Bambang Hanggono (Brackishwater Aquaculture Development Center, Situbondo, Indonesia) for kindly provided EHP DNA, Grant Stentiford (CEFAS Weymouth, UK) for an enlightening discussion about EHP.

\section{REFERENCES}

Aranguren LF, Han JE Tang KFJ. 2017. Enterocytozoon hepatopenaei (EHP) is a risk factor for acute hepatopancreatic necrosis disease (AHPND) and septic hepatopancreatic necrosis (SHPN) in the Pacific white shrimp Penaeus vannamei. Aquaculture 471: 37-42.

Desrina, Verreth JAJ, Prayitno SB, Rombout JHWM, Verdegem MCJ. 2013. Replication of white spot syndrome virus (WSSV) in the polychaete Dendronereis spp. J Invertebr Pathol 114: 7-10.

Ha NT, Dong HT, Thuy NgT, Lien NTK. 2010. Enterocytozoon hepatopenaei has been detected parasitizing tiger shrimp (Penaeus monodon) cultured in Vietnam and showing white feces syndrome. Khoa Hoc Cong Nge. Nong Nghiep Va PhatTrien Nong Thon. KY2Thang 12/2010: 45-50. [Vietnamese with English abstract] 
Han JE, Kim J, Jo H, Eun J, Lee C, Kim JH, Lee K, Kim J. 2019. Increased susceptibility of white spot syndrome virus-exposed Penaeus vannamei to Vibrio parahaemolyticus causing acute hepatopancreatic necrosis disease. Aquaculture. DOI: 10.1016/j.aquaculture.2019.734333.

Haryadi D, Verreth JAJ, Verdegem MCJ, Flak JM. 2015. Transmission of white spot syndrome virus (WSSV) from Dendronereis spp. (Peters) (Nereididae) to penaeid shrimp. J Fish Dis 38: 419-428.

Kummari S, Srinu R, Devika P, Gadasu R. 2018. Hepatopancreatic Microsporidiasis (HPM) in Shrimp Culture: A Review. Int J Cur Microbiol App Sci 7(1): 3208-3215.

Micieli MV, Garcia JJ, Becnel J. 2000. Horizontal Transmission of Amblyospora albifasciati García and Becnel, 1994 (Microsporidia: Amblyosporidae), to a Copepod Intermediate Host and the Neotropical Mosquito, Aedes albifasciatus (Macquart, 1837). J Invertebr Pathol 75: 76-83.

Praveena PE, Bhuvaneswari T, Krishnan AN, Jagadeesan V, Rajan JJS, Jithendran KP. 2018. An improved microscopic method for the rapid diagnosis of emerging microsporidian parasite, Enterocytozoon hepatopenaei in shrimp farms. Curr Sci 115. 758-763. DOI: $10.18520 / \mathrm{cs} / \mathrm{v} 115 / \mathrm{i} 4 / 758-763$.

Rajendran K, Shivam S, Praveena PE, Rajan JJS, Kumar TS, Avunje S, Jagadeesana V, Prasad Babua SVANV, Pandea A, Krishnana N, et al. 2016. Emergence of Enterocytozoon hepatopenaei (EHP) in farmed Penaeus (Litopenaeus) vannamei in India. Aquaculture 454: 272-280.

Solter LF. 2014. Epizootiology of Microsporidiosis in Invertebrate Host. In: Weiss L, Becnel JJ (eds) Microsporidia: Pathogens of Opportunity. John Wiley \& Son, Inc., New York.

Stentiford GD, Dunn AM. 2014. Microsporidian in Aquatic Invertebrates. In: Weiss L, Becnel JJ (eds) Microsporidia: Pathogens of Opportunity. John Wiley \& Son, Inc., New York.

Tang KF, Pantoja CR, Redman RM, Han JE, Tran LH, Lightner DV. 2015. Development of in situ hybridization and PCR assays for the 322detection of Enterocytozoon hepatopenaei (EHP), a microsporidian parasite infecting penaeid shrimp. J Invertebr Pathol 130: $37-41$

Tang KFJ, Han JE, Aranguren LF, White-Noble B, Schmidt MM, Piamsomboon P, Risdiana E, Hanggono B. 2016. Dense populations of the microsporidian Enterocytozoon hepatopenaei (EHP) in feces of Penaeus vannamei exhibiting white feces syndrome and pathways of their transmission to healthy shrimp. J Invertebr Pathol 140: 1-7.

Tangprasittipap A, Srisala J, Chouwdee S, Somboon M, Chuchird N, Limsuwan C, Srisuvan T, Flegel TW, Sritunyalucksana K. 2013. The microsporidian Enterocytozoon hepatopenaei is not the cause of white feces syndrome in white leg shrimp Penaeus (Litopenaeus) vannamei. BMC Vet Res 9: 139-139.

Thitamadee S, Prachumwat A, Srisala J, Jaroenlak P, Salachan PV, Sritunyalucksana K, Flegel TW, Itsathitpaisarn O. 2016. Review of current disease threats for cultivated penaeid shrimp in Asia. Aquaculture 452: 69-87.

Tourtip S, Wongtripop S, Steniford GD, Bateman KS, Sriurairatana S, Chavadej J, Sritunyalucksana K, Withyachumnarnkul B. 2009. Enterocytozoon hepatopenaei sp. nov. (Microsporidia: Enterocytozoonidae), a parasite of the black tiger shrimp Penaeus monodon (Decapoda: Penaeidae): Fine structure and phylogenetic relationships. J Invertebr Pathol 102: 21-29.

Varadharajan D, Soundarapandian P. 2013. Science of advance in aqua farming study of food and feeding habits of Jumbo Tiger Shrimp, Penaeus monodon (Fabricius, 1798) from Parangipettai, South East Coast of India. J Aquac Res Dev 4: 196 DOI: 10.4172/21559546.1000196

Vávra J, Larsson JIR. 2014. Structure of Microsporidia. In: Weiss L, Becnel JJ (eds.). Microsporidia: Pathogens of Opportunity. John Wiley \& Sons, Inc., New York.

Vijayan KK, Stalin Raj V, Balasubramanian CP, Alavandi SV, Thillai Sekar V, Santiago TC. 2005. Polychaete worms-A vector for white spot syndrome virus (WSSV). Dis Aquat Organ 63: 107-111. 